\title{
Health-related quality of life of adolescents in the context of selected somatic development indices
}

\section{Jakość życia związana ze zdrowiem młodzieży a wybrane wskaźniki rozwoju somatycznego}

\author{
Jadwiga Krawczyńska², Paulina Łukawska² \\ ${ }^{1} 1$ Department of Oncology and Nursing Oncology, Institute of Nursing and Obstetrics, Faculty of Health Sciences, \\ Jan Kochanowski University, Kielce, Poland \\ Head of the Department: Prof. JKU Maciej Kielar MD, PhD \\ 2Department of Publical Health, Faculty of Pedagogic, Old Polish University, Kielce, Poland \\ Head of the Department: Jolanta Góral-Półrola PhD
}

Key words: health-related quality of life, body mass index, adolescents.

Słowa kluczowe: jakość życia związana ze zdrowiem, wskaźnik masy ciała, młodzież.

\begin{abstract}
Introduction: The measurement of health-related quality of life (HRQOL) is nowadays one of the most important methods of self-assessment of health, which makes it possible to detect abnormalities in physical, mental, and social functioning. The weight-growth body mass index (BMI), which determines the degree of nourishment, is essential in the evaluation of the somatic development.

Aim of the research: The assessment of HRQOL depending on the weight-growth rate and gender of the pupils.

Material and methods: The study involved 588 pupils aged 16-18 years. The authors applied in the study the methods of survey and analysis of pupils' health records. The KIDSCREEN-52, designed to test the health-related quality of life, was the research tool. Results: The BMI analysis showed a clear advantage of pupils with normal weight. Among boys the percentage of individuals suspected of overweight and obesity was higher, whereas among girls the higher percentage involved individuals with body weight deficit. The results of HRQOL show that obese boys evaluated the highest their financial resources, autonomy, and relationships with parents. The pupils with body weight deficit evaluated the lowest their self-image. The overweight boys evaluated their mental wellbeing the lowest in comparison to others, and the highest their self-image. Overweight girls evaluated the lowest their self-image, emotions, and the school environment. The girls with body weight deficit evaluated the highest their relations with parents, and the lowest their autonomy.

Conclusions: The values of the BMI among the surveyed pupils show an explicit prevalence of individuals with normal body mass. The results of the pupils with eating disorders were lower in all categories of HRQOL. No dependence was confirmed between the BMIs of pupils and the results of the KIDSCREEN-52 questionnaire in any of the assessed category of HRQOL $(p>0.05)$.
\end{abstract}

\section{Streszczenie}

Wprowadzenie: Pomiar jakości życia związanej ze zdrowiem (HRQOL) jest obecnie jedna z ważnych metod samooceny zdrowia, która umożliwia wykrycie nieprawidłowości w funkcjonowaniu fizycznym, psychicznym oraz społecznym. W ocenie rozwoju somatycznego istotny jest wagowo-wzrostowy wskaźnik masy ciała (BMI), określający stopień odżywienia.

Cel pracy: Ocena HRQOL młodzieży w zależności od wskaźnika wagowo-wzrostowego oraz płci.

Materiał i metody: W badaniu uczestniczyło 588 uczniów w wieku 16-18 lat. Zastosowano metodę sondażu, technikę wywiadu oraz analizę dokumentacji zdrowotnej ucznia. Narzędziem badawczym był kwestionariusz KIDSCREEN-52 przeznaczony do oceny HRQOL młodzieży.

Wyniki: Analiza wartości BMI wykazała wyraźną przewagę uczniów o prawidłowej masie ciała. Wśród chłopców stwierdzono większy odsetek osób z podejrzeniem nadwagi i otyłości, natomiast u dziewczą - z niedoborem masy ciała. Wyniki HRQOL wskazują, że chłopcy z otyłością najwyżej ocenili zasoby finansowe, niezależność i relacje z rodzicami. Uczniowie z niedoborem masy ciała najniżej ocenili obraz własnej osoby. Chłopcy z nadwagą najniżej w stosunku do pozostałych ocenili swoje samopoczucie psychiczne, a najwyżej obraz własnej osoby. Dziewczęta z nadwagą najniżej oceniły obraz własnej osoby, nastroje, emocje i środowisko szkolne. Uczennice z niedoborem masy ciała najwyżej oceniły swoje relacje z rodzicami, a najniżej niezależność. Wnioski: Wartości BMI u badanych uczniów wskazują na wyraźną przewagę osób o prawidłowej masie ciała. Uczniowie z zaburzeniami odżywiania uzyskali niższe wyniki ocenianych kategorii HRQOL. Nie potwierdzono zależności pomiędzy BMI uczniów a wynikami kwestionariusza KIDSCREEN-52 w żadnej z badanych kategorii HRQOL $(p>0,05)$. 


\section{Introduction}

In recent years the approach to assessing the health of the population has changed. It also relates to the population in the developmental period. In line with the holistic concept of health, it is important to take into account in the study of the health-related quality of life the objective health determinants, including the indices of somatic development $[1,2]$.

The most commonly used positive measures include the indices of the physical development of children and adolescents, and in recent years also the measurement of subjective health and life satisfaction $[1,3]$. This study also refers to the selected indices of physical development, which are ranked among positive health measures.

A systematic assessment of the somatic development constitutes an integral part of the physical examination of each child, and is also one of the basic elements of preventive healthcare for children and adolescents [4]. The assessment that was conducted properly enables us to evaluate not only the condition of health, but also to determine whether the development of a child is in accordance with its genetic potential. A single assessment makes it possible to define only whether the degree of the child's development is appropriate, whereas repeated measurements allow tracking of the dynamics of the developmental processes.

Long-term observations provide much more information on the course of development and the impact of various factors (e.g. elimination diets used, nutritious deficiencies relating to quality and quantity, and mental stress), and also allows us to assess the effects of the treatment applied [5].

In all studies devoted to the problem under discussion it is emphasised that during the age of puberty one should take into account in the self-evaluation of health the aspects of physical, mental, and social functioning. It is extremely important in terms of development and health. The disharmony of the somatic and psychosocial development is very often the cause of behavioural disorders, addictions, and neuroses in the developmental period.

The level of self-responsibility for actions, knowledge of standards that should guide an individual in his/her behaviour, or the skills of coexistence with the environment and social sensitivity do not keep up with the accelerated physical and intellectual development [6].

A significant problem associated with physical development, which is related to the variables adopted in the study, is the level of acceptance of one's body as a symbol of the changed personality. This acceptance is expressed by the self-assessment of one's appearance.

For the majority of young people their physical features are often the cause of discontent and the desire to change their appearance. Their physical condition is a source of anxiety and concern as it may create difficulties in social relationships. People whose appearance does not meet the standards adapt worse than those with physical characteristics that are similar to the socially accepted ones $[7,8]$.

In practice, the evaluation of physical development is primarily concerned with the processes of growth. It is based on a comparison of measurement results of the somatometric features to the biological systems of reference, namely norms [5].

The results of height and weight measurements are the basis for this assessment at school age. They are performed as part of the screening tests to detect abnormalities in height or body weight. Tests can detect deviations from the norm, taking into account gender and age [4].

In recent years the criteria for evaluating the accuracy of body weight have changed. Nowadays body mass index (BMI), which represents the ratio of body weight to its height, is considered to be the most reliable reflection of the degree of nutrition $[4,9]$.

\section{Aim of the research}

The aim of the study was to evaluate the healthrelated quality of life (HRQOL) of adolescents depending on the weight and height rate and gender of the surveyed pupils. Specific problems were formulated in terms of this objective: What is the health condition of the examined adolescents on the basis of the physical development index-BMI? Is there a correlation between HRQOL and values of BMI?

\section{Material and methods}

The study was conducted among 588 second-grade secondary school pupils including 317 girls and 271 boys aged 16 to 18 years.

The method of a diagnostic survey with standardised interview technique was applied.

The research tool that was used was the questionnaire KIDSCREEN-52 Health-related Quality of Life Screening Instrument for Children and Adolescents, authors: THE KIDSCREEN GROUP EUROPE [10]. The authors used the Polish version of the questionnaire to study the health-related quality of life in the adaptation of Mazur et al. [11].

The analysis of pupils' health records was applied in order to obtain objective data on health indices of a pupil. Preventive examination cards were used as a source of information.

\section{Results}

In view of the global epidemic of overweight and obesity of children and adolescents there is a need to conduct reliable research and analysis on the basis of uniform criteria.

In order to normalise the criteria for the body weight assessment the International Obesity Task Force 
(IOTF) proposed averaged international standards based on the results of BMI studies involving populations of more than 10,000 children and adolescents aged $2-18$ years [12].

The studies refer to the BMI norms developed by Palczewska and Niedźwiecka in 2007, and contained in the tables of percentiles are values of BMI accordingly to the age and gender of the examined persons [7].

Percentile charts or BMI tables for age and gender are used to assess the degree of deficiency or excess of weight in the population in the developmental period [6]. Standardised tables called percentile charts have been used in paediatrics to assess the development of children and adolescents since the 1920s [13].

\section{Comparison and assessment of the BMI values depending on the gender of the respondents}

According to the criteria adopted while making the profile of the respondents in terms of weight and growth rate - body mass index - the normal weight was located between the $5^{\text {th }}$ and $85^{\text {th }}$ percentiles, weight deficiency was below the $5^{\text {th }}$ percentile, overweight was within the range $\leq 85^{\text {th }}$ and $<95^{\text {th }}$ percentile, and obesity was above the $95^{\text {th }}$ percentile $[4,5]$.

The BMI of each pupil was calculated, and the result was related to the percentile values in accordance with the procedures determined in the screening test for detecting disorders in the physical development of children and adolescents [4].

The values of the results indicate that the largest proportion of young people were adolescents with normal weight (72.28\%). Body mass index values indicating a risk of overweight were found in $10.54 \%$, a risk of obesity was seen in $9.18 \%$, and weight deficiency affected $7.99 \%$ of the pupils surveyed from all types of schools (Figure 1).

The analysis of the BMI depending on the gender of respondents indicated that both in the group of boys and girls the majority were individuals who did not show deviations from the norm in terms of BMI, which allowed us to define their weight as normal (73.39\% vs. $68.63 \%)$.

It was further stated that the risk of both overweight (13.28\% ) and obesity (11.07\%) prevailed explicitly among boys. On the other hand, among pupils with BMI indicating weight deficiency, the majority were girls (8.83\%) (Figure 2).

The analysis and assessment of HRQOL depending on the BMI and gender of the respondents

The study of health-related life quality was conducted using the Polish version of the questionnaire KIDSCREEN-52.
The questionnaire includes 10 areas (dimensions) that make up the profile of the quality of life. One dimension refers to physical health, and three areas are assigned to mental health: psychological wellbeing, moods and emotions, and self-perception.

Social functioning is reflected by five areas, including relationships with parents and family life, peer relationships and social support, autonomy, school environment, and social acceptance (understood as the absence of manifestations of bullying).

The last dimension, financial resources, refers to the assessment of material conditions

The pupils answered from the perspective of the past week, raw results were standardised on a scale of 0-100 points, resulting in mean indices of health-related quality of life according to the sum scale. Thanks to this, the natural differences between particular dimensions of HRQOL were retained, making it possible to interpret the result as a percentage of the maximum potential result $[10,11]$.

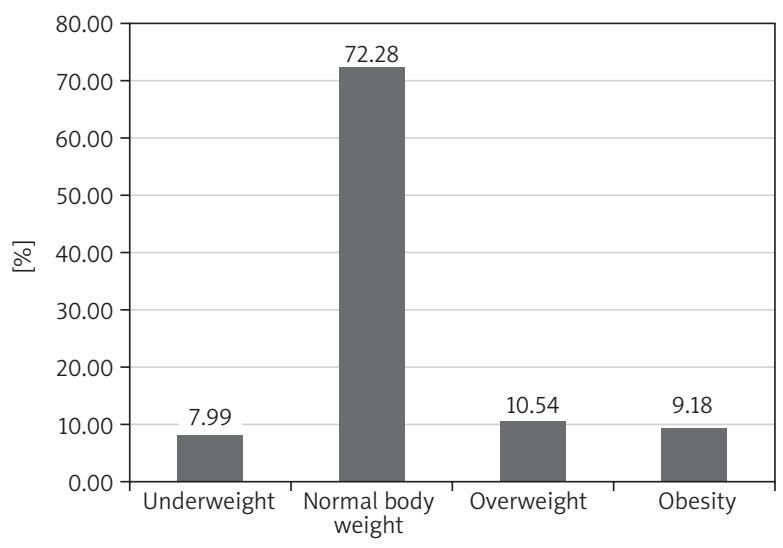

Figure 1. The values of the weight-growth rate - BMI in the examined group of adolescents

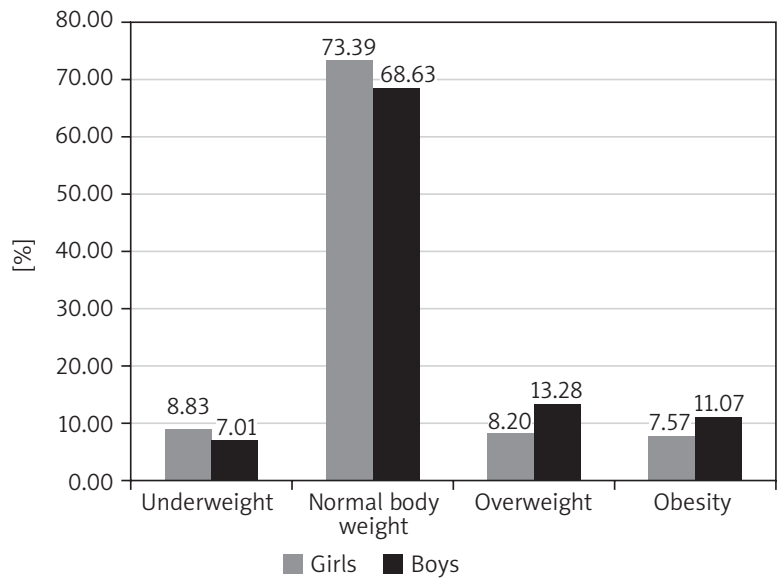

Figure 2. Body mass index values according to the gender of respondents 
The analysis of the health-related quality of life in the surveyed group of young people showed that overweight individuals evaluated the lowest, in comparison to others, their psychological wellbeing, mood and emotions, and the school environment, whereas the highest was the assessment of their physical wellbeing and social support of friends.

Obese pupils evaluated their autonomy, financial resources, moods, and emotions the highest and in no category of HRQOL were their results the lowest.

The pupils with body weight deficiency received the worst results in the following categories: autonomy, wellbeing, and self-image. However, in the four dimensions of HRQOL including social acceptance, relationships with parents, mental health, and school environment their assessment was the highest among all the respondents.

It should be emphasised that normal-weight adolescents received the lowest indices in four categories of HRQOL, and the score of only one category was the highest (Table 1 contains detailed results).

Analysing the results of the mean indices of life quality of adolescents according to the BMI category and gender, it should be stated that it is girls with overweight who received the lowest indices in the four dimensions, girls with obesity in two categories, and girls with weight deficiency in one, whereas normal-weight girls had the lowest indices in three categories. The results of obese girls suggest that they evaluated themselves the lowest in relation to other friends, in the dimensions of physical and mental wellbeing. The overweight respondents received the lowest values of HRQOL in dimensions such as the school environment, self-image, moods and emotions, as well as the relationships with parents and home. The students whose BMI indicated a body weight deficit evaluated their autonomy the lowest and their relationships with parent and the home environment the highest in relation to the others.
The results of boys with obesity and overweight indicate a more favourable, in comparison to the girls, evaluation of quality of life; their results were lower than the results of their friends only in terms of two categories: mental wellbeing and social acceptance.

Obese students obtained the highest indices of HRQOL in five categories such as physical wellbeing, autonomy, financial resources, social support and friends, and home environment, the lowest evaluated dimension was social acceptance.

Overweight students evaluated their self-image the best and their mental wellbeing the worst. The respondents with body weight deficit received the lowest values in the six dimensions: self-image, autonomy, financial resources, social and peer support, the school environment, and relationships with parents (Table 2, Figures 3 and 4).

The analysis of the results revealed that eating disorders are a factor affecting the self-evaluation of health and appearance of the young people examined; however, the differences were statistically insignificant. This is particularly true of girls with unfavourable assessment of their physical and mental health, and appearance.

In the case of boys, the HRQOL indices were more favourable compared to other evaluated categories of BMI. The analysis conducted did not confirm a relationship between the values of the weight-growth rate-BMI of boys and girls and the results of the particular dimensions of HRQOL measures with the KIDSCREEN questionnaire, in each case the result was statistically insignificant $(p>0.05)$.

\section{Discussion}

Eating disorders are among the most common disorders of physical development of children and adolescents. Due to their prevalence and dynamics of growth it is a serious public health problem. A real threat asso-

Table 1. Average HRQOL indices of surveyed adolescents according to BMI

\begin{tabular}{|lccccc|}
\hline $\begin{array}{l}\text { Category } \\
\text { KIDSCREEN }\end{array}$ & Underweight & $\begin{array}{c}\text { Normal } \\
\text { weight }\end{array}$ & Overweight & Obesity & $\begin{array}{c}\text { Standard } \\
\text { 15-18 years }\end{array}$ \\
Physical wellbeing & 58.51 & 58.94 & 60.00 & 59.54 & 62.60 \\
Psychological wellbeing & 59.13 & 58.89 & 56.38 & 57.87 & 60.55 \\
Moods and emotions & 67.48 & 67.47 & 66.82 & 68.32 & 72.18 \\
Self-perception & 60.43 & 62.93 & 61.61 & 62.04 & 63.46 \\
Autonomy & 54.68 & 56.73 & 58.23 & 60.83 & 58.30 \\
Parent relations and home life & 69.59 & 63.13 & 63.71 & 67.21 & 64.20 \\
Financial resources & 56.03 & 52.59 & 56.72 & 61.11 & 51.60 \\
Social support and peers & 60.73 & 59.48 & 60.69 & 60.26 & 59.74 \\
School environment & 45.83 & 45.31 & 43.41 & 44.91 & 49.22 \\
Social acceptance bullying & 91.67 & 89.75 & 91.40 & 89.81 & 91.13 \\
\hline
\end{tabular}


Table 2. Mean indices of HRQOL according to BMI and gender

\begin{tabular}{|c|c|c|c|c|c|c|c|c|c|c|}
\hline \multirow[t]{2}{*}{$\begin{array}{l}\text { Category } \\
\text { KIDSCREEN }\end{array}$} & \multicolumn{2}{|c|}{ Underweight } & \multicolumn{2}{|c|}{$\begin{array}{l}\text { Normal } \\
\text { weight }\end{array}$} & \multicolumn{2}{|c|}{ Overweight } & \multicolumn{2}{|c|}{ Obesity } & \multicolumn{2}{|c|}{$\begin{array}{c}\text { Standard } \\
15-18 \text { years }\end{array}$} \\
\hline & Girls & Boys & Girls & Boys & Girls & Boys & Girls & Boys & Girls & Boys \\
\hline Physical wellbeing & 52.50 & 67.37 & 53.14 & 66.40 & 50.96 & 66.53 & 49.17 & 67.83 & 59.13 & 66.92 \\
\hline Psychological wellbeing & 53.13 & 67.98 & 55.68 & 63.02 & 50.96 & 60.30 & 49.48 & 64.58 & 59.17 & 62.30 \\
\hline Moods and emotions & 63.39 & 73.50 & 64.84 & 70.85 & 59.75 & 71.92 & 64.43 & 71.43 & 68.66 & 76.60 \\
\hline Self-perception & 57.68 & 64.47 & 57.76 & 69.57 & 47.88 & 71.53 & 55.00 & 67.67 & 57.77 & 70.65 \\
\hline Autonomy & 48.75 & 63.42 & 52.03 & 62.77 & 52.12 & 62.64 & 52.08 & 67.83 & 54.48 & 63.14 \\
\hline Parent relations and home life & 71.88 & 66.23 & 59.40 & 67.92 & 57.85 & 67.94 & 63.89 & 69.86 & 62.67 & 66.14 \\
\hline Financial resources & 55.06 & 57.46 & 48.05 & 58.42 & 52.24 & 59.95 & 53.13 & 67.50 & 51.08 & 52.27 \\
\hline Social support and peers & 60.27 & 61.40 & 57.57 & 61.94 & 59.62 & 61.46 & 57.81 & 62.22 & 61.07 & 58.07 \\
\hline School environment & 47.47 & 43.42 & 44.86 & 45.90 & 41.67 & 44.68 & 43.75 & 45.83 & 50.06 & 48.15 \\
\hline Social acceptance bullying & 90.77 & 92.98 & 87.87 & 92.16 & 89.74 & 92.59 & 88.89 & 90.56 & 90.41 & 92.03 \\
\hline
\end{tabular}

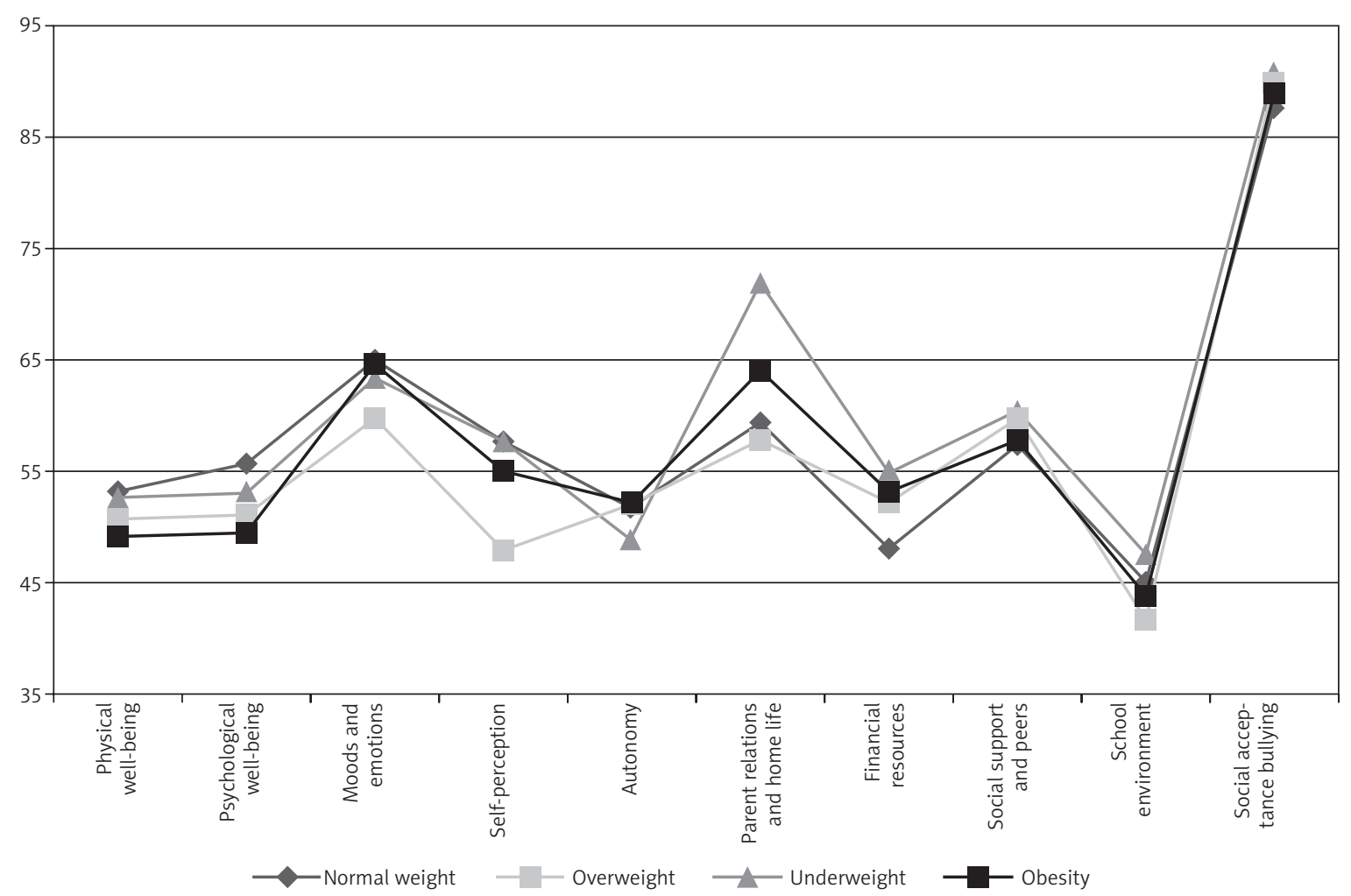

Figure 3. The HRQOL profiles of girls as per BMI

ciated with overweight and obesity during the developmental period is obesity at a later age and the risk of metabolic syndrome.

The International Obesity Task Force estimated in 1990 that overweight and obesity occurred in approximately $10 \%$ of children between 5 and 17 years of age. In 2005 a report (IOTF) was published, which demonstrated that the BMI of every fifth child in Europe indi- cates overweight or obesity, which accounts for 77-78.5 million children, and this number increases every year by about 400 thousand [14].

The escalation of the phenomenon of overweight and obesity among Polish children is not clear-cut due to various evaluation criteria and the diversity of age groups, which makes the results of different analysis impossible to compare. 


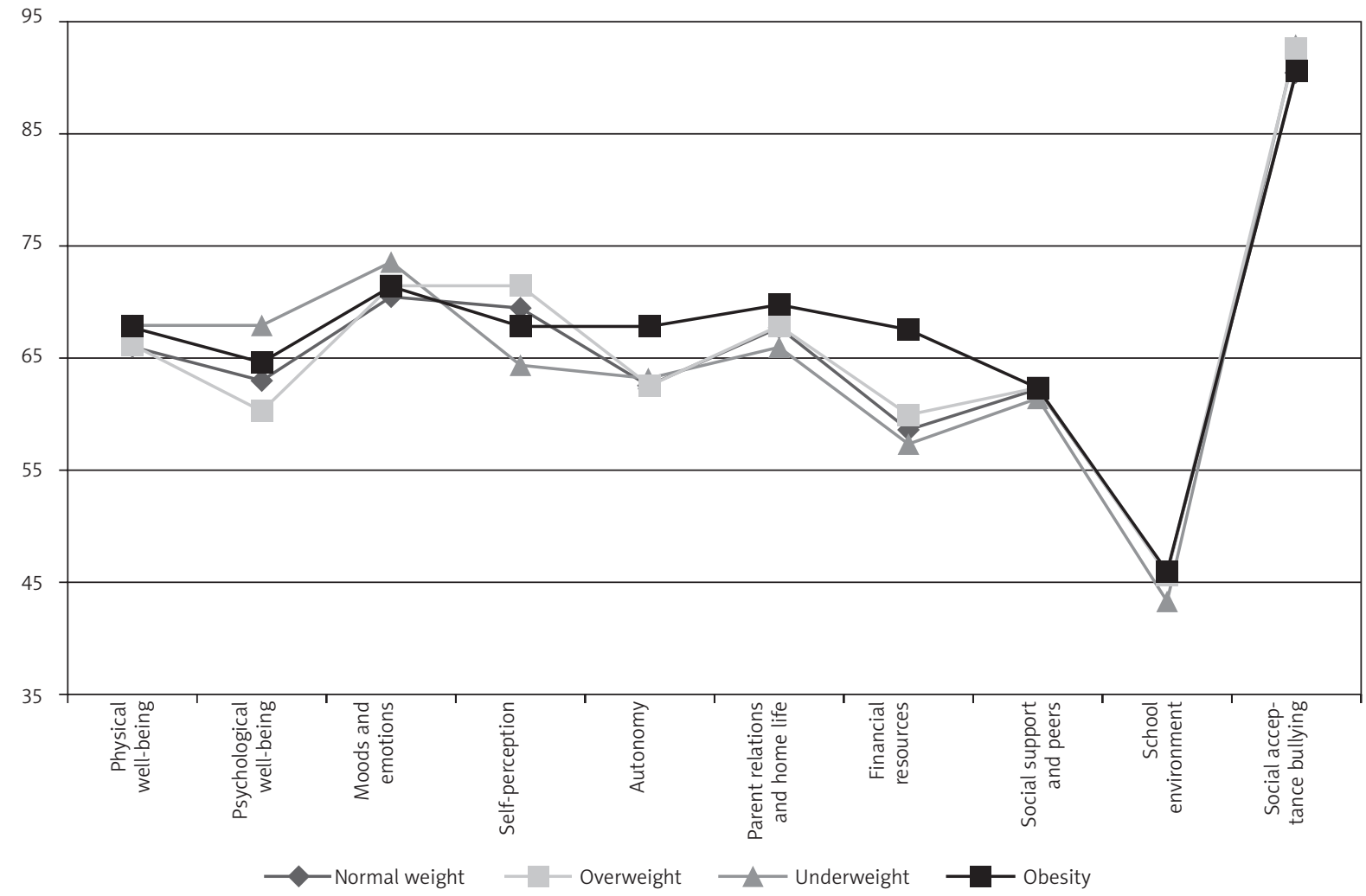

Figure 4. The HRQOL profiles of boys as per BMI

The results of the research of Krzyżniak conducted in 2008-2009 showed the phenomenon of body weight increase in all the categories of gender and age. Krzyżniak used in her study Cole's criteria, according to which the percentage of overweight children increased in the period of ten years, to $21 \%$ in boys and $15 \%$ in girls [15].

The results of the OLAF study on a representative sample of the population of school-age children and adolescents in Poland indicate that the excess weight (overweight and obesity in total) prevails in $16.4 \%$ of girls and boys aged 6-16 [16].

The dynamics of this phenomenon is confirmed by the UNICEF report, which shows that the weight gain of children in Poland is the fastest in Europe, and in the last decade its percentage has doubled. Such a large increase in this rate has not occurred in any of the 29 countries surveyed by UNICEF [17].

The analysis of the BMI results in the respondents showed an explicit prevalence of people with normal weight; overweight and obese young people constituted $19.2 \%$ of all respondents. This problem affects $15.77 \%$ of girls and $24.35 \%$ of boys. Among the boys the percentage of individuals with suspected overweight and obesity was greater, whereas among girls there were more individuals with body weight deficit.

Special attention should be paid to the fact that obesity in the Polish population is a serious mental and social problem. Eating disorders lead to depression among young people, the cause of which is abnormal BMI.

It was found that the higher the index the greater the intensity of depression. This is due to low self-esteem of the obese and lack of acceptance in the peer environment, which results in low quality of life of these individuals and increased suicide attempts among this group of young people. Obesity and overweight is one of the main factors causing a significant reduction of social needs in adolescence. This leads to social isolation and lack of sense of adequacy, and thus to emotional disorders $[18,19]$.

The conducted study showed no statistically significant differences in the results, referring to particular dimensions of HRQOL, between a group with proper BMI and a group with eating disorders. The results of HRQOL of pupils in the categories assessed by BMI show a slight variation in the dimensions such as physical and mental wellbeing, and self-image, and in this respect they are also much lower than the population norms.

Respondents whose BMI indicated the risk of obesity received more favourable results in comparison to other respondents. This concerned dimensions relating to financial resources and autonomy.

Students with weight deficit perceived their relationships with parents and the home environment 
much better, and the worst perceived was the scope of their autonomy.

Gender was the factor conditioning the subjective assessment of the health of adolescents. The results of HRQOL indicate that obese boys assessed the highest their financial resources, autonomy, and relationships with parents. The pupils with weight deficit assessed the lowest their self-image.

Overweight boys assessed the lowest in comparison to others their mental wellbeing, and the highest their self-image. Overweight girls assessed the lowest their self-image, moods and emotions, and the school environment. The girls with weight deficit evaluated the highest their relationships with parents and the lowest their autonomy.

The analysis and assessment of the health condition of children and adolescents and their predispositions constitute the basis for determining goals and taking organised actions in prevention and health promotion as part of national health programs [20].

In accordance with the holistic concept of health, it is important to take into account in the studies on the health-related quality of life its objective determinants including the somatic development indices.

\section{Conclusions}

The BMI values in the surveyed group of pupils indicate an explicit prevalence of individuals with normal weight. The profiles of health-related quality of life of adolescents with eating disorders show a trend towards lower results of HRQOL. The study failed to confirm the relationship between the BMI values of pupils and the results of the KIDSCREEN-52 questionnaire in any of the assessed categories of HRQOL $(p>0.05)$.

\section{Conflict of interest}

The authors declare no conflict of interest.

\section{References}

1. Mazur J, Szumska-Olczak A. Mierniki oceny w programach promocji zdrowia - wybrane podejścia modelowe. Med Wieku Rozwoj 2000; 49: 53-66.

2. Nutbean D. Evaluating health promotion-progress, problems and solutions. Health Promot Int 1998; 13: 27-44.

3. Wojtyniak B, Goryński P. Elementy metodologii określania potrzeb zdrowotnych. Wyd. PZH, Warsaw 2001.

4. Jodkowska M, Woynarowska B, Oblacińska A. Test przesiewowy do wykrywania zaburzeń w rozwoju fizycznym u dzieci i młodzieży w wieku szkolnym. Materiały metodyczne dla pielęgniarek szkolnych oraz lekarzy podstawowej opieki zdrowotnej. IMiDz, Warsaw 2007.

5. Krawczyński M. Norma kliniczna w pediatrii. Wydawnictwo Lekarskie PZWL, Warsaw 2005.

6. Rybakowa M. Medycyna wieku młodzieńczego: wybrane problemy endokrynologiczne i psychospołeczne. Rola lekarza rodzinnego. Post Nauk Med 2006; 6: 325-32.
7. Palczewska I, Niedźwiecka Z. Wskaźniki rozwoju somatycznego dzieci i młodzieży warszawskiej. Med Wieku Rozwoj 2001; 5: 113-4.

8. Zięba E, Nowak-Staż G, Karakiewicz B, Markowska M, Krawczyńska J, Skawiński D. Rozwój somatyczny dziewcząt $\mathrm{z}$ zaburzeniami miesiączkowania i bez zaburzeń w stanie zdrowia i rozwoju w aspekcie wybranych wskaźników wagowo-wzrostowych. Studia Medyczne 2012; 25: 51-9.

9. Matusik P, Małecka-Tendera E, Nowak A. Metody stosowane $\mathrm{w}$ praktyce pediatrycznej do oceny stopnia odżywienia dzieci. Endokr Otyłość Zab Przem Mat 2005; 1: 6-11.

10. The KIDSCREEN Group Europe. The KIDSCREEN Questionnaires - Quality of life questionnaires for children and adolescents. Handbook. Pabst Science Publishers, Lengerich 2006.

11. Mazur J, Małkowska-Szkutnik A, Dzielska A, Tabak I. Polska wersja kwestionariusza do badania jakości życia związanej ze zdrowiem dzieci i młodzieży (KIDSCREEN). IMiDz, Warsaw 2008.

12. Dietz WH, Bellizzi MC. Assessment of childhood and adolescent obesity: results from an International Obesity Task Force Workshop. Am J Clin Nutr 1999; 70: 117S-75S.

13. Brosco JP. Weight charts and wellchild care: how the pediatrician became the expert in child health. Arch Pediatr Adolesc Med 2001; 155: 1385-9.

14. Iwańczak B. Wpływ otyłości na występowanie chorób przewodu pokarmowego. Pediatr Współcz Gastroenterol Hepatol Żyw Dziecka 2010; 12: 45-9.

15. Krzyżniak A. Zdrowie poznańskich uczniów. Wydawnictwo Miejskie, Poznan 2009

16. Grajda A, Kułaga Z, Gurzkowska B, Napieralska E, Litwin M. Regional differences in the prevalance of overweight, obesity and underweight among Polish children and adolescents. Med Wieku Rozwoj 2011; 15: 258-65.

17. UNICEF Office of Research. Child well-being in rich countries. A comparative overview. Innocenti Report Card 11 UNICEF Office of Research, Florencia 2013.

18. Mojs E, Daroszewski P. Psychospołeczne skutki otyłości u dzieci i młodzieży. Piel Pol 2012; 3: 155-9.

19. Romańczyk A. Otyłość - współczesna choroba cywilizacyjna. In: Zagrożenia zdrowia chorobami cywilizacyjnymi. Pedagogiczne konteksty badawcze. Bulska J (ed.). Oficyna Wydawnicza Impuls, Krakow 2008; 69-93.

20. Zięba E, Markowska M, Krawczyńska J, Zięba P, NowakStarz G. Evaluation of life quality associated with health of girls aged 13-14 in groups with menstrual disorders and no disorders in health and development in the light of the questionnaire KIDSCREEN-52. Studia Medyczne 2013; 29: 213-8.

\section{Address for correspondence:}

\section{Dr. Jadwiga Krawczyńska}

Department of Oncology and Nursing Oncology Institute of Nursing and Obstetrics

Faculty of Health Sciences

Jan Kochanowski University

al. IX Wiekow Kielc 19, 25-317 Kielce, Poland

Phone: +48 506733624

E-mail: jadwigakrawczynska@o2.pl 